\title{
Adhesion Factor Production
}

National Cancer Institute

\section{Source}

National Cancer Institute. Adhesion Factor Production. NCI Thesaurus. Code C40695.

Any cellular process that results in the elaboration of adhesion molecules on the cell surface. 